\title{
ГРИГОРЯН ВИОЛЕТТА
}

Доцент кафедры русского языка и

профессиональной коммуникации

Российско-Армянского (Славянского) университета, кандидат педагогических наук

\section{КОНЦЕПТОСФЕРА РУССКОГО ЯЗЫКА В СИСТЕМЕ ИЗУЧЕНИЯ ХУДОЖЕСТВЕННОГО ТЕКСТА}

Приобщение к русской культуре через художественную литературу представляется нам важным в процессе вузовского обучения РКИ, поскольку это может способствовать развитию мышления, приобщению к новой концептосфере, что, в свою очередь, поможет эффективной аккультурации учащихся в процессе создания вторичной языковой личности на уроках русского языка. В настоящей статье мы попытаемся рассмотреть концептосферу русского языка в системе изучения художественного текста.

Ключевье слова и словосочетание: художественный текст, обучение русскому языку, концептосфера русского языка, русская культура, национальная культура, национальное мышление, приобщение к новой культуре.

В настоящее время методисты-русисты нашей республики в процессе вузовского обучения русскому языку все чаще обращаются к произведениям художественной литературы, что можно только приветствовать, поскольку именно художественная литература обладает огромной силой воздействия и мощным арсеналом, способным активизировать мышление учащихся. В настоящей статье мы попытаемся рассмотреть кониептосферу русского языка в системе изучения художественного текста.

Вопрос о природе общих понятий или концептов - старый вопрос, давно стоящий на очереди, но почти не тронутый в своем центральном пункте, особенно в методическом аспекте.

Проблема концептов и проблема художественного слова имеют не только общие точки соприкосновения, но в основном положительно совпадают. Слова в одном случае (проблема концептов), не вызывая никакого познавательного “представления”, понимаются и создают нечто, могущее быть объектом точной логической обработки. В другом случае (проблема художественного слова) слово, не вызывая никаких художественных “образов”, создает художественное впечатление, имеющее своим результатом какие-то духовные обогащения [2: 47].

Что это за туманное “нечто” в области знания и в искусстве слова, и в чем заключается его основная ценность? В проблеме познания это “нечто” носит название “концепта”, под которым надо понимать два его вида: “общее представление” и “понятие”. В проблеме искусства это “нечто” пока еще не связано с определенным четким термином. Его можно условно назвать “художественным концептом” с полным сознанием имеющихся в данном случае существенных отличий. Именно художественный концепт и входит в сферу наших интересов.

Чтобы подойти к уяснению природы концептов, необходимо уловить самую существенную их сторону, как познавательных средств, поскольку именно 
познавательные средства являются краеугольным камнем любой методики обучения. Эту сторону мы видим в функции заместительства. Концепт есть мыслительное образование, которое замещает нам в процессе мысли неопределенное множество предметов одного и того же рода [4: 93]. Не следует, конечно, думать, что концепт есть всегда заместитель реальных предметов. Он может быть заместителем некоторых сторон предмета или реальных действий, как, например, концепты “справедливость”, “законность”, “смелость”, “мужество”, “ненависть” и т. д. Наконец, он может быть заместителем разного рода хотя и весьма точных, но чисто мыслительных функций. Таковы, например, математические концепты.

Концепты познания - общности, концепть искусства - индивидуальны. Художественный концепт чаще всего есть комплекс того и другого, то есть сочетание понятий, представлений, чувств, эмоций, иногда даже волевых проявлений. Самое же существенное отличие художественных концептов от познавательных заключается все же именно в неопределенности возможностей. В концептах знания эти возможности подчинены либо требованию соответствия реальной действительности или же законам логики. Связь элементов художественного концепта зиждется на совершенно чуждой логике и реальной прагматике художественной ассоциативности. Нельзя сказать, что в этой ассоциативности не было своей закономерности и требовательности [3: 54]. Но они все же не укладываются ни в какие правила и представляют в каждом отдельном случае особую индивидуальную норму вроде нормы развития музыкальной мелодии.

Таким образом, природа художественных концептов частично совпадает с природой концептов познания. В них тоже есть своя заместительная сила, поскольку то, что они обозначают, больше данного в них содержания и находится за их пределами. Именно ассоциативная запредельность придает им своеобразную художественную ценность.

Художественный концепт не есть образ или если и содержит его, то случайно или частично. Но он, несомненно, тяготеет именно прежде всего к потенциальным образам и так же направлен на них, как и познавательный концепт направлен на конкретные представления, подходящие под его логический “родовой” объем.

В художественном концепте есть тоже свое “родовое”, однако оно совершенно свободно от рамок логического определения. В нем “родовое” есть органический сросток возможных образных формирований, определяемый основной семантикой художественных слов.

В каждом художественном концепте заключена как бы задача найти по части целое. Пусть это целое никогда вполне не развертывается. Но самое важное, что вы имеете ключ к его раскрытию, потенциально им обладаете, то есть и здесь, как в познании, потенциальному принадлежит определенное значение и ценность. Потенциал здесь иногда как бы упирается в невозможность в смысле раскрытия. Ценность этого невозможного особенно ясна в концептах художественно-эмотивных, то есть заключающих не только потенцию к раскрытию образов, но и разнообразие волнующих чувств и настроений. Неопределенное “нечто”, обещаемое в первичном значении, то есть нечто, которое мы даже бессильны вполне раскрыть в направлении обещанного, отличается иногда чрезвычайной остротой художественного воздействия. Таковы, например, концепты ужаса, страха, горя, любовного очарования, счастья, радости и т. д. Здесь неизвестное и как бы 
бездонное нечто в этом роде волнует нас гораздо глубже, чем раскрытое или легко раскрываемое.

Какое из словарных значений слова замещает собой концепт, выясняется обычно из данного контекста, а иногда даже из общей представленной конкретной ситуации. Концепт не непосредственно возникает из значения определенного слова, а является результатом столкновения словарного значения слова с личным и народным опытом человека, что обязательно необходимо учитывать в учебном процессе, поскольку личный опыт у разных людей имеет различный объем, в то время как народный опыт это достояние каждого члена общества.

И слово, и его значения, и концепты этих значений существуют не сами по себе в некоей независимости, а в определенной человеческой “идеосфере”. у каждого человека есть свой, индивидуальный культурный опыт, запас знаний и навыков (последнее не менее важно), которыми и определяется богатство знаний слова и богатство концептов этих значений, а иногда, впрочем, и их бедность, однозначность.

Чем меньше культурный опыт человека, тем беднее не только его язык, но и “концептосфера” его словарного запаса, как активного, так и пассивного, что в конечном итоге обусловливает узость его мировоззрения. Имеет значение не только широкая осведомленность и богатство эмоционального опыта, но и способность быстро извлекать ассоциации из запаса этого опыта и осведомленности.

Концептосфера национального языка тем богаче, чем богаче вся культура нации - ее литература, фольклор, наука, изобразительное искусство (оно также имеет непосредственное отношение к языку и, следовательно, к национальной концептосфере), она соотносима со всем историческим опытом нации и религией особенно. Это обязательно следует учитывать при обучении РКИ, поскольку в данном случае мы говорим о возникновении новой языковой личности путем соприкосновения с новой концептосферой, ибо у учащихся уже сформирована своя национальная концептосфера, а новая концептосфера может оказаться чуждой.

Концепты создаются не только в индивидуальном опыте человека, и не все люди в равной мере обладают способностью обогащать концептосферу национального языка. Особое значение в создании концептосферы принадлежит писателям и поэтам, носителям фольклора, отдельным профессиям и сословиям (особенно крестьянству). Поэтому представляется очевидным, что концепты имеют не только слова, но и фразеологизмы, являющиеся также образными заместителями отдельных понятий [5: 193]. Именно поэтому фразеологизмам следует уделять большое внимание в процессе обучения.

В концептосферу входят также названия произведений, которые через свои значения порождают концепты. Так, например, когда мы говорим “Обломов”, мы можем, грубо говоря, разуметь три значения этого слова:

- название известного произведения Гончарова;

- героя этого произведения;

- определенный тип человека.

И вот в зависимости от того, читали ли мы Гончарова, насколько глубоко и по-своему поняли его и сблизили со своим культурным и национальным опытом, все три компонента будут в пределах контекста различаться по смыслу и “потенциям”. Тем не менее, для каждого человека, хорошо знакомого с русской 
литературой, слово “Обломов” говорит чрезвычайно много. В потенции в нашем сознании со словом “Обломов” возникает целый ряд различных ассоциаций с миром столичной и деревенской жизни, миром русского характера, сословных и возрастных особенностей и т. д.

Концептосфера русского языка, созданная писателями и фольклором, необычайно богата. Концептосфера русского языка - это в сущности кониептосфера русской культурьл. Характерно, что поэты, начавшие писать стихи на русском, больше всего благодаря богатству своей концептосферы, приспособленной для поэзии своими потенциальными возможностями, не могут перейти на другой язык [6: 79].

Итак, богатство языка определяется не только богатством словарного запаса и грамматическими возможностями, но и богатством концептуального мира, концептуальной сферы, носителями которой является язык человека и его нации. Поэтому, при обучении РКИ очень важно (и необходимо) учитывать возможности соприкосновения учащихся с богатствами концептуального мира другой нации и культуры в аспекте духовного обогащения личности.

Концептуальная сфера, в которой живет любой национальный язык, постоянно обогащается, если есть достойная его литература и достаточный культурный опыт. Она трудно поддается сокращению, редуцированию. Это происходит только в тех случаях, когда пропадает культурная память народа в широком смысле этого слова.

Понятие концептосферы особенно важно тем, что оно помогает понять, почему язык является не просто способом общения, но неким концентром культуры - культуры нации и ее воплощения в разных слоях населения вплоть до отдельной личности. Уже самый поверхностный взгляд на концептосферу русского языка демонстрирует исключительное богатство и многообразие русской культуры, созданной за тысячелетия в разных сферах жизни и в различных соотношениях с культурами других народов. Таким образом, овладевая русским языком как иностранным, учащиеся имеют возможность приобщиться к русской культуре.

Каждое литературное произведение воплощает индивидуально-авторский способ восприятия и организации мира, то есть частный вариант концептуализации мира. Выражаемые в литературнохудожественной форме знания автора о мире являются системой представлений, направленных адресату. В этой системе наряду с универсальными общечеловеческими знаниями существуют уникальные, самобытные, порой парадоксальные представления автора. Таким образом, концептуализация мира в художественном mексте, с одной стороны, отражает универсальные законы мироустройства, а с другой - индивидуальные, даже уникальные, воображаемые идеи. Степень соответствия универсальных и индивидуально-авторских знаний в художественной картине мира текста может быть различна: от полного совпадения, тождества до разительного несовпадения, полного расхождения. Вследствие этого слова-концепты художественного мира вряд ли могут быть четко и безоговорочно определены и описаны, в их концептосфере, согласно законам порождения и восприятия текста, может быть множество совершенно различных личностных смыслов.

Таким образом, концептуальный анализ художественного текста в учебном процессе предполагает:

- во-первых, выявление набора ключевых слов текста; 
- во-вторых, описание обозначаемого ими концептуального пространства;

- в-третьих, определение базового концепта (концептов) этого пространства.

Индивидуально-авторская картина мира имеет в тексте, как правило, ярко отраженный характер, она в большей степени субъективна и несет в себе черты языковой личности ее создателя. Это обусловлено эстетическим характером отражения действительности и антропоцентризмом текста.

Продуктивным способом описания индивидуально-авторской картины мира является концептуальный анализ художественного произведения, который заключается в выведении из содержания всего авторского текста базового, основного концепта, а также различных сведений, знаний о концепте, составляющих его концептосферу. В литературно-художественном тексте осуществляется эстетическая концептуализация мира, проявляющаяся в том, что автор как творческая личность, наряду с общепринятыми знаниями, привносит в представления о мире и свои частные, индивидуальные знания.
Аспекты концептуализации обусловлены:

- во-первых, объективными законами мироустройства;

- во-вторых, оценочной индивидуальной позицией автора, его углом зрения на факты реальной действительности.

Выдвижение обнаруживается в актуализации определенных свойств и признаков объекта, избранных в качестве существенных при актуализации. В свою очередь, аспекты актуализации во многом объясняют полевую структуру концептосферы, которая зависит от способов языковой репрезентации концепта [1: 82-105].

Таким образом, приобщение к русской культуре через художественную литературу представляется нам важным в процессе обучения РКИ, поскольку это может способствовать развитию мышления, приобщению к новой концептосфере, что, в свою очередь, поможет эффективной аккультурации учащихся в процессе создания второй языковой личности на уроках русского языка.

Дата представления статьи 20.05.2013

\section{ЛИТЕРАТУРА}

1. Бабенко Л. Г. и др. Лингвистический анализ художественного текста. Екатеринбург, 2000.

2. Солганик Г. Я. От слова к тексту. М.,1993.

3. Степанов Ю. С. Между “системой” и “Текстом”: выражения “фрактов” // Язык - система. Язык - текст. Язык - способность: К 60-летию чл.-корр. РАН Ю.Н. Караулова. М., 1995.

4. Степанов Ю. С. Слово: Из статья для словаря концептов: Концептуарий русской культуры // Philologica, 1994, N 1-2.

5. Телия В.Н. Вторичная номинация и ее виды // Языковая номинация: Виды наименований. М., 1977.

6. Чернухина И. Я. Поэтическое речевое мышление. Воронеж, 1983. 


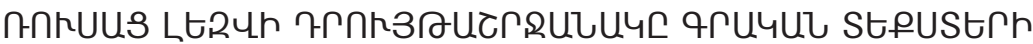

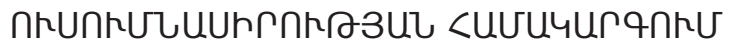

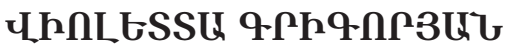

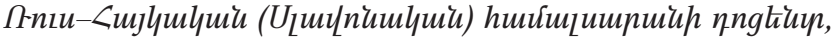

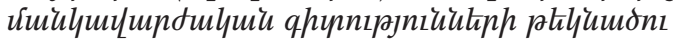

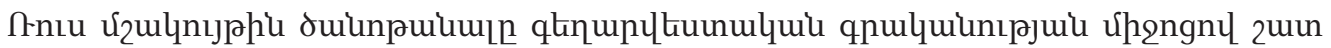

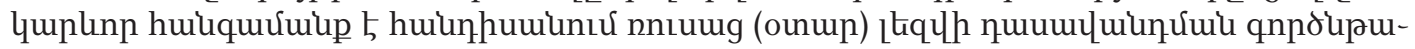

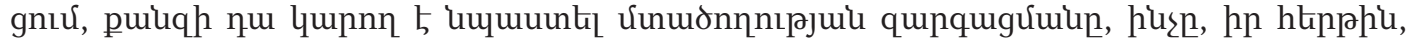

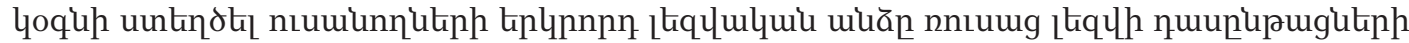

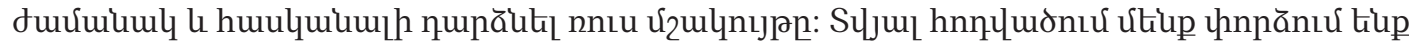

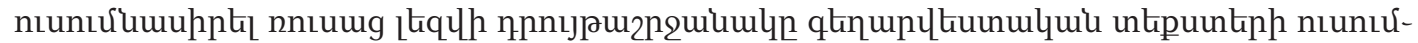
umuhnnıрјщu hứulqunqnıर्u:

\section{SPHERE CONCEPT OF RUSSIAN LANGUAGE IN THE STUDY OF LITERARY TEXT VIOLETTA GRIGORYAN}

Associate Professor of the Chair of the Russian Language and Professional Communication of Russian-Armenian (Slavonic) University, Ph.D in Pedagogical Sciences

Joining Russian culture through literary texts is very important in the process of learning Russian as a foreign language (RFL). It may promote to intelligence of mode of thinking, attached to a new sphere concept, which can effectively help students to be acculturated in the process of creating a second language person at lessons of Russian language in higher school. In the present article we attempt to examine the sphere concept of the Russian language in the system of literary text study. 